Carlos Préndez Saldías

\title{
POETAS CHILENOS EN ATENEA
}

通

ABLAR de la poesía en Atenea es citar los nombres de los más destacados valores líricos del país.

La poesía chilena que, a partir de Pedro A. González, o más propiamente desde la renovación literaria propiciada por Marcial Cabrera en las páginas de Pluma y Lápiz, comenzó a tener un significado en América, ha seguido desarrollando su trayectoria y critalizando, en más de un caso, emociones personales inconfundibles, inquietudes estéticas fervientes, o, simplemente, acentos armoniosos de un límpido lirismo.

No es poco. Al concepto general de nuestra negación imaginativa, las generaciones del novecientos respondieron animosamente. No sería exagerado citar hoy veinte nombres cuyas calidades no desmerecen en la poética de América.

- La crítica de nuestros días ha sido un poco injusta con los renovadores, valdría decir con los iniciadores del movimiento lírico chileno. González, Bórquez, Contreras, si no hicieron obra estética pura, tienen el mérito inmarcesible del estímulo hacia la liberación de pautas arcaicas, en las que rara vez-la excepción de Blest Gana-vibró la emoción íntima.

Malogrado González por la obsesión del ritmo y el rebuscamiento sonoro, enredado Bórquez en la maraña de sus mitos extravagantes, deslumbrado Contreras con el esplendor de los modelos franceses, no exteriorizaron en obras de lograda poesía el tesoro personal de que en algunos momentos dieran muestra.

Tras ellos apareció en las letras un espíritu noblèmente dotado. Un poeta de raza, fuerte y conmovido: Carlos Pezoa Véliz.

Sin reminiscencias serviles, alejándose de los moldes en uso, atento sólo a los ecos que en su espacio interior produjeran el espectáculo del paisaje y las almas de su tierra, cantó en poe. mas viriles con propia entonación. 
Por esa misma época, Víctor Domingo Silva hacía vibrar en cálidas estrofas entusiastas afanes de reivindicación social, y Diego Dublé Urrutia y Samuel Lillo consolidaban sus prestigios de evocadores afortunados de costumbres y tierras sureñas.

De 1910 a 1920 la poesía chilena alcanza sus planos más claros y oxigenados. Ahonda y se concreta en evidentes expresiones personales. Y de entre el grupo de poetas surge la voz estremecida y singular de una mujer que 'suspende en emoción a cuantos vibran con el soplo intangible.

Uabriela Mistral se destaca a raíz de un concurso literario con el signo inequívoco de los elegidos.

Versos vitales, torturados, prenetrantes. Circula por ellos la savia de un turbio dolor que ha ceñido para siempre jamás un alma intacta de mujer.

A la admiración suscitada por los Poemas de la Muerte, Gabriela Mistral suma el acervo imaginativo y emocional de toda su obra posterior.

Es el poeta enaltecido y sereno. No llora su dolor. Con él cava y edifica en la tierra de su espíritu. Una fuerza religiosa y magnífica suspende sus manos y su voz. Su acento es limpio y florecido, aunque su verso se desarticula y se violenta con renovada insistencia. Ciencia o intuición, el hecho es que tales sobresaltos - inadmisibles cuando exceden los límites de una liberación rítmica razonable-parecen en el caso de la Mistra! irrumpir también desde su hondor espiritual, y son como otro atributo de su poesía.

Alguien ha hablado de su ausencia de feminidad. Acaso predispone a tal engaño su fuerza espiritual. Porque es ilógico pedir femenidad después de leídos aquellos inefables Poemas de la Madre, maravilla de intuición femenina.

No es la fuerza íntima de Gabriela Mistral el tremor cálido y envolvente de la Agustini, aquella gran hermana primogénita de las poetisas de América, a quien ninguno de los altos valores líricos femeninos del continente podría desconocer como a la oficiante inicial de la sinceridad en la introspección. Pero, como en ella, el amor es en Gabriela la inquietud excelsa. Lo que en Delmira Agustini es ansiedad vehemente y gloriosa, en Gabriela Mistral es soledad, ahondamiento, evocación sensorial, y luego, reacción filosófica hacia la ensoñación dolorida.

Después de «Desolación», Gabriela Mistral parece haber dirigido sus preferencias a la prosa, colaborando en las más prestigiosas publicaciones hispanoamericanas. En ellas se des- 
taca siempre la poetisa. Imágenes. Sentimientos. Esta prosa, - hay que decirlo-es con frecuencia demasiado erudita, difícil, perezosa. No agrega valor a los blasones del poeta.

- Jorge González Bastías.-Sus primeros versos vieron la luz en el ya citado heraldo histórico de Pluma y Lápiz. Poeta bucólico con un fino y personalísimo sentido de la naturaleza, nadie como él ha obtenido notas de poesía tan pura interpretando el alma de sus paisajes serranos. Si Max Jara lograra la máxima sencillez de expresión, González ha conseguido aprisionar en sus aspectos sutiles la emoción desnuda.

Su primer libro "Misas de Primavera» reveló a un espíritu armonioso, sentidor, enamorado de su tierra:

$$
\begin{aligned}
& \text { «aquellos esteros y aquella montaña } \\
& \text { y aquellos caminos se acuerdan de mí.» }
\end{aligned}
$$

Años más tarde aparece el «Poema de las Tierras Pobres», canto conmovido, fraternal, untuoso, en que se vive la tragedia de los cerros, otrora fecundos, esperanzados, después empobrecidos, estériles, diezmados por la voracidad de banderías políticas.

Próximo a editarse está "Vera Rústica», el libro más definido de Jorge González. Poemas hay en esas páginas en los que el engaste verbal, depurado hasta la ingravidez, intenta desaparecer para que la poesía, liberada, emerja desnuda.

Del poema "Los ecos perdidos» son las estrofas que siguen:

Habla una anciana de cabellos blancos:

\section{- Gran Dios! tanto vivír!}

$\mathrm{Y}$ este cansancio largo, interminable, de hablar, de ver, de oír.

Este cansancio que es como la muerte uniforme y fatal,

que hasta en las piedras deja una invisible, tenebrosa señal.

Los hombres ya no pueden con el peso de la fatiga atroz,

andan como sonámbulos, rendidos, olvidados de Dios.

A qué vivir, a qué esperar el tiempo que ha de ser siempre igual.

El pobre no levantará su casa... no se hará bien del mal: 
Manuel Magallanes Moure.-Poeta intenso y emocionado. Sensibilidad y sutileza presiden toda su obra. Fluye de su canto una pena amable y tranquila que aunque se haga dolor nunca llega al grito o la estridencia. Tampoco a la monotonía, a pesar de su tono insistentemente velado, porque su fino tacto artístico percibe y refleja con segura intuición idiomática los más leves latidos de su activa vida interior.

Su estrofa es así, plena, seductiva, con cierta íntima resonancia, todo ello revestido de aristocrática sencillez.

Con los más logrados poemas de Magallanes, como "Apaisement", "Madre mía", ocurre el caso paradojal de que, leídos los versos-continente armonioso y admirable-parecen estos desaparecer, trasmutarse, y en los oídos del espíritu queda sonando la "poesía", la intima, la imponderable. Revelación de un estro ungido en profundidad y en meditación, cualidad insigne de poeta.

\section{APAISEMENT.}

Tus ojos y mis ojos se contemplan en la quietud crepuscular.

Nos bebemos el alma lentamente $y$ se nos duerme el desear.

Como dos niños que jamás supieron de los ardores del amor, en la paz de la tarde nos miramos con novedad de corazón.

Violeta era el color de la montaña. Ahora azul, azul está.

Era una soledad el cielo. Ahora por él la luna de oro va.

Me sabes tuyo, te recuerdo mía. Somos el hombre y la mujer.

Conscientes de ser nuestros, nos miramos en el sereno atardecer.

Son del color del agua tus pupilas: del color del agua del mar.

Desnuda, en ellas se sumerge mi alma con sed de amor $y$ eternidad. 
Max Jara.-Su primer libro "Juventud» bastó para revelarlo como poeta tocado de frescura y emoción.

"Mi madre fué como ella cuando niña.

Ambas han de llorar cuando me muera.»

Artista verdadero, presiente y coge ágilmente la expresión sintética, cabal, superándose a veces en el hallazgo feliz:

«Me duele el corazón como una herida»

En «¿ Poesía. . . ?», su segundo libro, el poeta explora sus zonas. interiores, y pone en su voz vibraciones doloridas. Más tarde esta crisis se tempera, y en "Asonantes" el escritor se nos presenta sereno y transparente.

No creemos que "Asonantes" agregue valores específicos a. la poesía de Jara; pero los agrega, sí, a sus atributos estéticos. Acaso nunca en nuestras letras se ha conseguido llegar a simplicidad tan limpia como en este libro. La canción infantil y el viejo romance castellano recobran en él olvidados prestigios.

Damos un fragmento de su romance "Yerbas Buenas":

Yerbas-Buenas de Linares:

casas grises, pardas vegas;

esteros bordan trigales;

alamedas, alamedas,

y palomas y campanas

en el vuelo de la queda...

Yerbas-Buenas de Linares, quien te gozó, la doncella,

la más hermosa te sabe

del mar a la cordillera.

¡Cómo dicen con tu nombre

glorias de la Patria Vieja

que cuanto más viejas, más

orgullosamente suenan,

sin halago de alabanzas,

porque solas ya son bellas!

¡Visión de aguas, tierra y luz,

dame paz en la conciencia!

Por el ansia de vivir,

por el dolor de belleza

con que desde que nací

esta mi vida se queja;

para bien de nuestros hijos,

Dios te guarde, Yerbas-Buenas. 
Carlos Mondaca.-Exaltación, fervor, musicalidad, son cualidades características de Mondaca.

«Tu cuerpo entero como un árbol canta».

Nuestra vida pasa. La flor se deshoja!

pero el fruto queda como mancha roja

cuando en otra vida la flor se deshoja».

Excesivo y elocuente en sus primeros libros, se acendra más tarde en las páginas de "Recogimiento». Hábil arquitecto verbal, no consigue, sin embargo, llegar hasta la sugerencia sino por excepción:

«Pasa en la sombra de la tarde, Fausto.»

Su tristeza es clara y tangible. En la exaltación íntima, en la ternura dolorida, el poeta da voces más penetrantes:

Es mi dolor ipobre de mí!

que no he podido eternizar!

Limitación para sufrir

y pequeñez para gozar!

En toda la producción de Mondaca se advierte la inquietud de una angustia ancestral, aplacada apenas por su afán místico constante, por su anhelo inquebrantable de fe, acaso por su fe misma.

De ahí surge la verdadera personalidad del poeta, del místico transido de sentimientos emotivos:

.....me encerraré en el fondo de mi alma adormecida.

Cerraré mis oídos para todo rumor

del mundo, y en mis ojos, que sellará el amor, alboreará la aurora del Señor».

Una de sus composiciones más celebradas, la «Elegía Civil»canto rebelde y doliente-muestra uno de los nobles aspectos de Mondaca: su hombría para decir en alejandrinos quemantes, de cara al tirano, la desolación de la patria.

$\checkmark$ Juan Guzmán Cruchaga.-La elegancia en el decir es, indudablemente, la cualidad máxima de este poeta. Conocedor profundo del ritmo, sabe hallar siempre la palabra precisa, de eufonía perfecta, que dé a su verso entonaciones musicales a la sordina y le haga perdurar con delicadeza de sonata íntima. 
Temperamento emotivo muy similar al de Juan Ramón Jiménez, más de algún comentador ha querido ver en su obra la influencia directa y no disimulada del gran lírico español. $\mathrm{Y}$ si esto pudo decirse, con escaso fundamento, de su obra inicial, con la publicación de «Agua de Cielo» demostró el carácter propio de su visión poética.

Espíritu sutil, delicado, en que no cabe la ruda sentimentalidad de América, habría que buscarle entroncamiento con los románticos alemanes o los poetas subjetivos que desde Francia echaron a volar su palabra entristecida hacia los cielos del mundo.

El poema "Lejana», demasiado extenso para transcribirlo íntegro, muestra, acaso más que cualquiera otro, las condiciones líricas de Guzmán Cruchaga.

Damos aquí algunos fragmentos:

Jazmines del Cabo. Noche de meditaciones grises.

Fragancia pura y doliente de jardines imposibles.

Tus pensamientos de nieve perfuman todo lo triste.

Jazmines del Cabo. Noche de meditaciones grises.

Me está diciendo el aroma lo que nunca me dijiste.

El barco navega cerca de la costa. Un rumoroso viento mueve los ramajes meditabundos y torvos. Es en la tarde. Una vaga tarde que enciende fastuosos rumores en la infinita calma de los mares solos. Un cuervo. Un cuervo. En el mástil se ha detenido. El medroso vuelo de la noche avanza. Un cuervo va con nosotros...

Angel Cruchaga Santa María.-A pesar de sus grandes valores poéticos, la obra de Cruchaga puede acusarse de monótona. 
Un misticismo repetido, y expresado desde su obra inicial con iguales palabras y con imágenes idénticas, da eñ toda sú la bor de veinte años la sensación de un temperamente estrufado que no ha sabido renovarse.

Las mujeres lejanas y las cabelleras infinitas cruzan y cruzan por su estrofa correcta en procesión enfermiza, y dan caracteres de alucinación a lo que tal vez sólo sea fuerte pasión de hombre sin pasiones.

Tiene Cruchaga en la poesía chilena un sitio bien personal, y la lírica del Continente no ha dado tampoco un poeta que se le asemeje,

Si el autor de «Las manos juntas» publicase una selección de sus versos, espigando cuidadosamente entre lo ya editado y su labor inédita, quedaría junto a los grandes líricos indiscutibles. Habría que eliminar de esa selección, claro está, todas las repeticiones de tema y de forma, por desgracia harto comunes en la obra de Cruchaga.

De su libro "Job», publicado en 1922, copiamos este poema:

\section{LA EVOCACION DE JOB}

Santo del muladar, terrible santo, tu alarido de piedra hacia el Eterno es una torre trémula de espanto.

¿Con tu cilicio se aromó el infierno!

Santo de Hus: tus llagas y tus manos

fecundaron las rosas.

Diste un rayo de luz a los gusanos y hablaste del Mesías a las cosas.

Inefable profeta de Idumea, Padre del mundo, de la muerte abuelo, tu azul desgarramiento fué una tea sumergida en la noche y en el cielo.

¡Oh milenario surco del tormento, tu voz se alzó como una espina terca hacia la amarga luz del firmamento! ¡Nadie estará de Dios nunca más cerca!

De tu sangre celeste y melodiosa brotó la cruz y apareció el Mesías que volaba como una mariposa sobre la santa hoguera de Isaías. 
¡Santo del muladar, lepra que canta

hacia los siglos como un bosque eterno!

Fué toda melodía tu garganta.

¡Aun la oye Luzbel en el infierno!

Daniel de la Vega.-Aunque este poeta ha callado en los últimos años, cogido por el diario ajetreo periodístico, su labor lírica ya realizada le coloca entre los poetas chilenos de primera línea.

Claro y hondo, su verso sencillo ha vibrado en todas las cuerdas de la lira. Desde el poema recogido en que canta la venida del primer hijo hasta la vibrante oda a la Alemania imperial del año 14. Sin olvidar su tragedia "Ménade» que, como obra dramática de arte puro, sin miras al escenario, no ha sido superada en América.

Nada dice mejor de su manera y de su orientación artística que estos propios versos del poeta:

Las palabras humildes son armoniosos vuelos de pájaros errantes que no han venido al mundo.

Cada una posee un sentido profundo.

Hablar con sencillez es un don de los cielos.

Tienen un resplandor inmortal. Es preciso saber amar las buenas palabras transparentes.

Yo las amo. Conozco sus perfiles ardientes. Cada palabra tiene su oculto paraíso.

Son arcas de milagro. Nuestros grandes anhelos se dicen con palabras claras. La poesía de verdad amanece más diáfana que el día. Hablar con sencillez es un don de los cielos.

La poesía de Daniel de la Vega tiene un sello inconfundible de grandeza y de simplicidad. Acaso sus convicciones teosóficas, que conocimos fuertes y arraigadas hace catorce o quince años, y que tal vez sean sus convicciones de hoy, hayan hecho el milagro de hermanar el pensamiento hondo y la transparencia diáfana de su forma rítmica.

Aunque sin alcanzar la fluidez de expresión que distingue la estrofa de Magallanes Moure, ha logrado el dominio de todas las formas métricas, incluso el exámetro ya olvidado. Está entre los poetas de más clara estirpe que han nacido entre nosotros. 
Copiamos parte de unos de sus poemas, publicado en 1919.

\section{CUANDO TU LLEGUES}

Señor, aquí me tienes esperándote, fervoroso y desnudo, con mi pequeña lámpara encendida a los pies del futuro.

No sé por qué camino viene el himno de tu perfil augusto, pero siento el rumor de tu sandalia en mi corazón mudo.

No sé por qué horizonte tu silueta ha de asomarse al mundo, pero este año las rosas nacen vueltas hacia el Oriente rubio...

Cuando tú llegues, besaré la tierra en señal de saludo, y apagaré mi lámpara, ya inútil en tu día profundo.

Cuando tú llegues, me darán las cosas sus sentidos ocultos, y mi vida será tan dulce como la luna en el crepúsculo.

Cuando tú llegues abriré mis puertas para que entre el júbilo del viento, y para ver los nuevos signos de los cielos nocturnos.

Porque se poblarán de estrellas nuevas los cielos del futuro cuando bajo los pechos de los hombres se callen los orgullos.

Y en nuestros ojos quedarán tan sólo rencores moribundos, deshaciéndose en lágrimas, fragantes como de un llanto tuyo. 
Cuando tú llegues guardaré silencio,

$\mathrm{y}$ así mis versos últimos

quedarán convertidos en alegres

pájaros errabundos...

Pablo Neruda.-Ningún poeta chileno ha sido elogiado con mayor apasionamiento que Pablo Neruda. Sus libros "Crepusculario» $y$ "Veinte Poemas", que mostraron un poderoso temperamento lírico, sin dar la obra definitivamente lograda, despertaron entre los muchachos de su generación un ansia enloquecida de batirle palmas y un peligroso afan de imitación.

Apareció Neruda en una época en que la aspiración suprema del escritor-del lírico especialmente-era la originalidad. Pero como ser original dentro de la sencillez resultaría obra de genios, el joven poeta se esforzó por invadir los nebulosos laberintos en que ofician ultraístas y suprarrealistas.

Sufrió con ello menoscabo su ingénito vuelo personal. La influencia extraña aparece en él visible y desordenada; pero, dotado de una aguda sensibilidad, logra ponerse en equilibrio, y aun imprimir a veces cualidades personales a sus poemas de amor $\mathrm{y}$ a sus canciones desesperadas.

Sin un control mental muy sólido, le han desvanecido no poco los elogios, y ha buscado de sumar a ellos el prestigio de innovador. Pretensión lamentable, ya que él es sensibilidad pura.

Hay en Neruda una gran fuerza sensual trasmutable, pero no tiene discernimiento poético. Carece de penetración inteligente, $\mathrm{y}$ su nota más conmovedora es el alarido.

Cuando ahonda en la oscuridad, pretendiendo obtener sensaciones o sugestiones nuevas, su voz se diluye vanamente, sin otro sentido estético que un noble, pero fracasado afán desuperación.

Pasará, como ya murieron otras escuelas y otras modas, este delirio innovador que atormenta a tantos poetas actuales, y las obras que con este afan se realizan sólo quedarán como piezas curiosas para los buzos literarios del porvenir.

Va aquí un fragmento de un bello poema de su «Crepusculario»:

Se llama y nadie responde,

se anda por seguir andando.

Andar, andar... ¿Hacia dónde?

¿Y hasta cuando?

Nadie responde

$y$ se sigue andando. 
Amor perdido y hallado y otra vez la vida trunca.

iLo que siempre se ha buscado

no debiera hallarse nunca!

Uno se cansa de amar...

Uno vive $y$ se ha de ir.

Soñar... ¿Para qué soñar?

Vivir... ¿Para qué vivir?

Hemos esbozado, sin otras pretensiones que fijar en sus aspectos más salientes, la personalidad de los poetas que han colaborado en AtenEa. Sería tarea de más aliento y reposo el estudio completo de estos y otros líricos cuyos valimientos justifican una atención concienzuda 